Divya Singh

\title{
Pathological Alteration in Thymus of White Leg Horn Chicks during experimental Ascaridiasis
}

\author{
Divya Singh \\ Asstt. Prof, Deptt. of Zoology, Meerut College, Meerut (India) \\ email:divyasingh134@gmail.com
}

Reference to this paper should be made as follows:

Divya Singh,

"Pathological Alteration in Thymus of White Leg

Horn Chicks during experimental Ascaridiasis", Voyager: Vol. IX, No. 1,April 2018, pp. 8 - 12

voyger.anubooks.com

\begin{abstract}
W.L.H. chicks were infected with A galli eggs dose (1000 eggs) and cadmium acetate treatment (5 mg. /Kg. body wt) was given. Pathological study of thymus was done after 30days of post infection and treatment. Mild depletion of lymphocytes was observed in cortex region. Inflammatory edema was due to infiltration of red blood cells. Medullary region revealed marked array of pathology.

Keywords : Thymus, W.L.H. chicks, ascaridiasis, A galli, lymphocytes, Inflammatory edema, Cadmium acetate
\end{abstract}


Introduction :-

Indian poultry has shown spectacular progress transforming itself from backyard farming to a dynamic and sophisticated agro-based industry. Eggs and chicken meat are one of the cheapest sources of protein available to Indians and as such can be immense help in fighting protein malnutrition in India. Parasitic infections account for hundred millions of dollars in annual losses and medicated costs in livestock and poultry industry throughout the world. The most costly parasites in terms of production losses are gastrointestinal nematodes in ruminants and poultry. (Gamble and Zarlenga, 1986).

Ascaridiasis is a gastro intestinal disease and is caused by an enteric nematode parasite, Ascaridia galli. (Schrank, 1788 and Freeborn, 1923). Kuscu and Gurel (2008) described about lesions in thymus and bone marrow in chicks with experimentally induced chicken infectious anemia disease.

Cadmium $(\mathrm{Cd})$ in an environmental pollutant and is non-degradable at environmental levels. Cadmium is toxic to a number of organs such as liver, Kidney, bone, blood, thymus, spleen and immune system (Friberget al, 1986; Goering et al. 1995). Combined effects of Parasitic infections and metal toxicity have been studied by few workers. (Long and Kougut; 1981; Bafundo et al 1984; Southern and Stewart, 1984 and Brown and Southern, 1985).

Materials and Methods

Newly hatched W.L.H. chicks were kept in clean cages in animal house. They were provided with feeding and water properly in morning and evening. To avoid metabolic variations, feeding was stopped 24 hours before commencement of experiments.

Culturing of Eggs :- Female parasites were kept in petri dish containing saline water for egg laying at $37^{\circ} \mathrm{C}$ in incubator. Eggs were kept in sterile solution at $32-37^{\circ} \mathrm{C}$ for embryo nation for 20 days. Dilution method was used for counting of eggs. The inocula with desired number of embryonated eggs (1000 embryonated eggs). were administered orally to WLH chicks Thymic tissues were got for pathological studies.

Administration of $5 \mathrm{mg} / \mathrm{Kg}$ body $\mathrm{Wt}$ dose of cadmium acetate to WLH chicks.

Dose with desired amount of Cadmium acetate was administered orally with help of 18 gauge feeding needle, mounted on graduated syringe.

Chicks were divided into 3 groups.

Group 'A' - Control group which was uninfected - 8 chicks

Group 'B' - Chicks given infection with 1000 embronated eggs of Ascaridia galli - 8 Chicks.

Group ' $\mathrm{C}$ ' - Chicks given infection with 1000 embryonated eggs of $A$ galli and treatment of Cadmium acetate given - 8 Chicks

Thymus was removed and kept in $10 \%$ neutral buffer formalin. Eosin and Hematoxylin were used for staining of sections.

Microphotography of sections was performed. 
Divya Singh
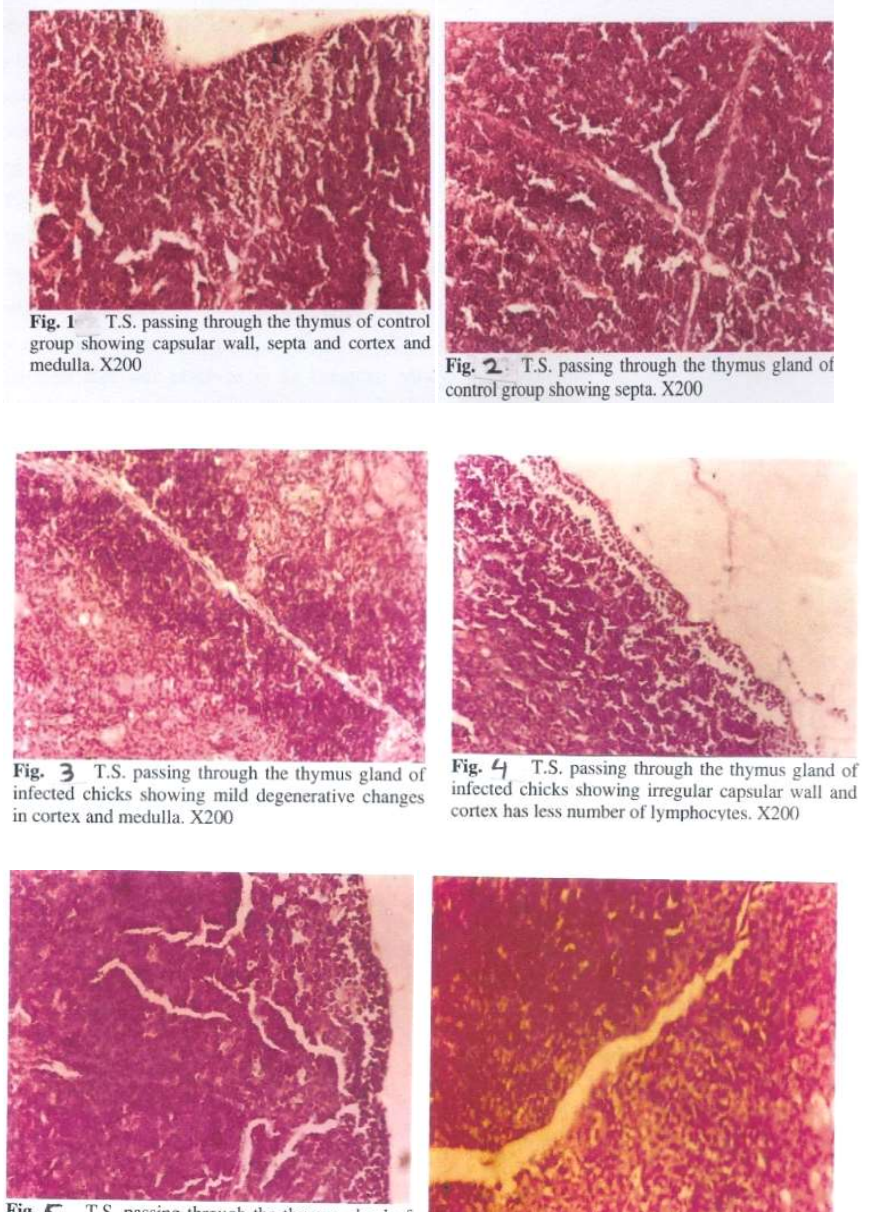

Fig 5 T.S. passing through the thymus gland of Inflammatory edema due to infiltration of red blood cells in cortex region and in medulla. X200

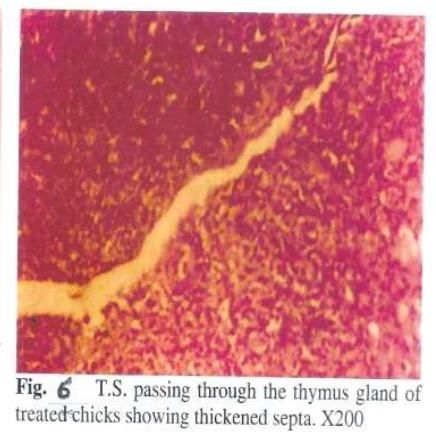

Results :

Group A - (Fig. 1,2) Structure of Thymus of (Control) Chicks.

Thymus gland is considered as primary lymphoid organ. The gland was encapsulated in a thin connective tissue. The mass of gland was divided into lobules by septa. Each lobe was divided into 2 region cortex and medulla.
Cortex - The Outermost region of each thymic lobule constituted cortex and was in continuation with capsule. The dense population of small lymphocytes predominated the other type of cells including reticular cell in cortex.

Medulla - The central region of thymic lobe comprised the medulla. It showed small population of lymphocytes. Thymic corpuscles 
were infrequently observed along with degenerating reticular cells.

Group 'B' - (Fig. 3, 4) - Structure of Thymus of infected chicks with embronated eggs. Capsular wall was observed to be irregular. Cortex has less number of lymphocytes and showed thymic atrophy. There were gap at certain places and inflammatory edema due to infiltration of lymphocytes was observed. Mild degenerative changes in cortex and medulla were observed. Degeneration of reticular cells was found to be prominent.

Group 'C' - (Fig. 5, 6) -Structure of thymus of chicks infected with embryonated eggs and treatment of Cadmium acetate given.

Capsular wall was found to be irregular, septa which divides thymus in lobes were thickened. Distribution of small and medium sized lymphocytes was seen. In medulla region, some vacuole type structures, were observed which contained degenerating lymphocytes.

Inflammatory edema due to infiltration of red blood cells in cortex and in medulla was seen.

\section{Discussion}

In the present study, it has been observed that $A$ galli. infection and heavy metal exposure in WLH chicks induced pathological alterations in thymus gland. The capsular wall and cortical region of thymus of all experimental groups did not show much pathological changes, but in medullary region, the lymphocytic population were found to be depleted and reticular cells were degenerated. These changes may be due to Vaso active amines and chemotoxins related during antigen antibody interactions. The chemotoxins reach into medullaand cause degeneration of thymic medulla. Thymic follicle hyperplasia and proliferation of mononuclear thymus dependent cells in Paracortical area were indicative of both cell mediated and humoral responses. Vaziry et al (2011) studied that chicken infectious anaemia vaccinal strain persist in thymus of young chicks and induces thymic lymphoid cell disorders. Selivanova et al (1977) reported pathological changes caused by Ascarissuum in a non specific host, the chicks. Zembrazuski (1978) studied the effect of lethal dose of Ascaris suum eggs on liver, lungs, spleen of guinea pigs during experimental infection. Clayton et al (1980) reported patho physiological changes associated with Parascaris equorum.

Pazyjalkowski and Watson (1980) studied pathological changes in small intestine of mice infected with Trichinella spiralis.

Atrophic changes displayed by prominent reduction of lymphocytes, were recognized in thymus. Thymus also shows infiltrationof plasma cells and macrophages. (Massfield, 1979). It is evident from present investigation, the variety of histo pathological changes in lymphoid organ of WLH host induced by $A$. galli infection and cadmium acetate treatment, depend upon severity of degree of infection.

In addition of being heavy metal, cadmium is a toxic metal, chronic exposure to which has been involved in variety of pathological alteration. 
Pathological Alteration in Thymus of White Leg Horn Chicks during experimental Ascaridiasis

Divya Singh

\section{Reference :}

Bafundo K.W., Baker, D.H. and Fitzgerald, P.R., (1984). Lead toxicity in chick as affected by excess copper and zinc and by Eimeria accervilia Infection Poult Sci. 63, 1594-1603.

Brown, DR and Southern, L.L. (1985) Effect of Eimeria accervulina infection in chicks fed excess dietary cobalt or manganese. Jour. Mutr 115, 347-351.

Clayton, H.M., Duncan, J.L. and Dargie J.D. (1980) Pathophysiological changes associated with parascaris equorum, Equne vet J., 12, 23-25.

Freeborn, S.B (1923). Nicotine is a Poultry vermifuge science 57, 693.

Friberg, L., Elinder C.G., and Nard berg G (1986). Cadmium and health. A toxicological and epidemiological appraisal Vol. 1, General aspects, Vol II Effects and Response, CRC Presss Inc, Boca Roton, Fla, 1986.

Gamble, H.R. and Zarlenga, D S (1986). Biotechnology in development of vaccines for animals parasites Vit Parasitol 20, 237-250.

Goering, P.L., Wailbos, M.P. and Klaasen C.D. (1995). Toxicology of cadmium. In toxicology of metals. Biochemical aspects (R.A. Goyes and M.G. Cherian Eds) hand Boolts of experiment pharmacology vol. 115 PP. 189-213, Springer - verlay New York.

Kuscu B., Gurel A. (2008). Lesions in thymus and bone marrow in chicks with experimentally induced chicken infectious anemia disease. $J$ vet Sci 9 (1), 15-23.

Long. P and Kougut, M. (1981) The effect of silica injections on rejections of Eimerio from non-specific host Journ of Parasitol. 67(6).

Schrank (1788). Cited in nematode parasites of domestic animals and of man by N.D. Levine. Buraess publishing company, Minnesota 316-365.

Selivanova A.S., Molodykh Z.H.V. and Pavlov O.V. (1977). The pathogenesis of helminthiasis, Veterinarnogo institution, Nie Baumona, 123-2-126.

Southern LL., Stewart T.B. (1984). Performance and tissue copper. Concentrations of control and Ascaris suum infected pigs fed excess dietary copper. J Parasitol 70(5), 668-70.

Vaziry A, silim. A, Bleau C, Frenette D, Lamontagne L (2011) Chicken infectious anaemia vaccinal strain persists in spleen and thymusof young chicks and induces thymic lymphoid cell disorders Avian Pathol 40(4): 377-85.

Zembrazuski. K (1978). Liver and lungs of guinea pigs experimentally infected with lethal doses of Ascaris suum eggs. Wiad Parazytol 24(4), 413-7. - 